\title{
Problems Analysis and Solutions of Oral English teaching in Vocational Colleges
}

\author{
Lihong Wang ${ }^{a}$, Weijie Gou ${ }^{\text {b }}$ \\ Beijing Polytechnic Beijing, China, 100176 \\ awlhjane@126.com, bgvjie@126.com
}

Keywords: Vocational College English; Oral English Teaching; Analysis of Problems; Strategies

\begin{abstract}
English has become an integral part in work and communication, so the oral English teaching has also become a vital part of foreign language teaching in China. However, due to the influence of traditional teaching for many years, currently in the English teaching of vocational education, the teaching level of oral English is low and teaching effect is poor. In this article, problems in oral English teaching of vocational college are analyzed, and strategies of oral English teaching reform are presented.
\end{abstract}

\section{Introduction}

Currently the teaching modes of Higher Vocational Education copy from universities, which lack features and advantages. In vocational colleges, there are many problems in English teaching, especially oral English teaching, and oral English teaching in vocational colleges is largely hampered by traditional teaching, and seldom develops students' practical ability to speak English. Even after several years of English learning the students cannot communicate in English. Therefore, the current priority is to find solutions and strategies for the problems of oral English teaching of vocational collegess.

\section{Problems in Oral English Teaching in Vocational Colleges}

There are no features in English Curriculum in Vocational Colleges. The traditional knowledge-based teaching mode of college English courses to teach the language is still used in English teaching of vocational colleges, and students' listening and speaking skills cannot be enhanced, which is inconsistent with the current requirements of vocational English Teaching. In most vocational colleges, English course is divided into two categories - intensive reading and listening, but the proportion of intensive reading course is too high. However, due to the constraints of teachers and class size, there are only some listening centralized training exercises or there are not listening classes at all.

In oral English teaching of vocational colleges, the teaching content is very limited, and is confined to everyday English or some written languages. Many vocational English courses are completely out of touch with the professional courses, do not reflect the vocational specialties, and many students find what they learnt in class cannot be used in work.

Evaluation System of English teaching and English teaching objectives in Vocational colleges do not match. According to the basic requirements of vocational English course, the main purpose of English teaching is to improve students' ability to use English to communicate, including daily communication skills and business communication skills. Current English teaching evaluation system and teaching goals are not matching. The most direct expression is that in the national English Test, oral English does not account for the proportion of the scores, and score of written exam is the only standard of evaluating students' learning achievement and teachers' teaching ability. Ministry of 
Education demands and called for the increase of students' English comprehensive ability, while educational administrative departments and vocational colleges take the rate of passing exam as the main teaching objectives of the actual teaching activities in Vocational College and evaluate students' English level. It's no doubt that the deviation of English teaching goals and dislocation of teaching evaluation weaken the oral English teaching.

Outdated teaching methods and insufficient practical vocational training in Oral English teaching of Vocational colleges. In the traditional teaching, "at the beginning students are trained to accurately express themselves, that is the training of accurately verbalizing the meaning". In the phase of students' language practice, if teachers teachers frequently interrupt students' oral exercises and correct their pronunciation and grammar, or even evaluate students' oral proficiency primarily by the accuracy of pronunciation and grammar, it is undoubtedly a kind of pressure for students who already lack of confidence when they speak English, and it is easy to dampen students' enthusiasm and self-confidence in speaking English.

Generally speaking, teachers must acknowledge students' ability of use English is poor, in actual communication, although many people learn English for many years, they cannot hear or speak English yet, this will cause a deformity of English learning phenomenon ---"deaf English" or "dumb English" ---spoken English skills cannot meet the demands of society. Input and output of language are closely linked in language acquisition, "language input" has been taken seriously in China's foreign language teaching, while "language output" is relatively neglected.

Neglect of English cultural background and thinking. For a long time, in English teaching, China's English teachers often tell students to master certain vocabulary, ask students to understand the grammar and sentence structure, do more exercise, recite model essay etc. Hardworking students did like that, it took them a lot of time to learn English, and also they achieved good results in English exams, but they cannot really communicate with English-speaking people. In the language communication, if teachers do not understand the cultural background of the other country, it will often cause a lot of pragmatic failures, which even makes others feel rude and malicious, and it is more likely to cause communication barriers than grammar and vocabulary. Because the East and the West belong to two different cultural systems, people's thinking patterns vary greatly. When learning English students not only learn the language itself, but also know and understand the cultural background of the language.

\section{Solutions to the Problems of Oral English Teaching in Vocational Colleges}

Adjust English teaching curriculum in vocational colleges and improve evaluation system. Oral English should be one part of English course, and English curriculum is divided into four blocks, English speaking, listening, reading, writing, they have different emphases, without neglecting the overall relevance of knowledge structure and skills in English, and ensure the integration and coherence of input and output of knowledge. Taking into account the characteristics of persistence of oral English learning and vocational students' low level, time of oral English class should be appropriately increased, the "four" skills and basic knowledge of English (vocabulary and grammar) should be combine in teaching.

Oral English should be included in the summative evaluation system---national English test, making it a truly comprehensive test of English proficiency, and truly become a measure of students' English ability of the four skills. The purpose of English teaching in vocational colleges is to develop students' ability of practical application of the language, and the purpose of the test is to make objective, accurate and fair assessment for students' language ability, to reflect the strengths and weaknesses in teaching, and provide scientific and objective basis for the improvement of teaching. Therefore, as a practical and effective means to assess the language ability, oral English test is essential in the whole language test. If oral English test is included in national English test, teachers and students 
will pay great attention to oral English, which will play a good role in improving students' speaking ability.

Adjust teaching strategies based on the particularity of teaching objects. The special nature of the teaching objects in higher vocational colleges should be taken into account: poor English level, inadequate confidence, weak motivation to learn, so the teachers should recognize that spoken English cannot be improved within a short period of time.

Improve students' spoken English gradually:

Improve students' oral English level step by step. English level can be improved only through long-term study, and it cannot be done overnight. Only through listening, reading, writing, large amounts of information can be input, and then output, that is the content of speaking. Only in this way can the persistence of students' learning English be enhanced. Teachers should take individual differences of students into consideration, and teach students in accordance of their aptitude. In oral English teaching, teachers should fully understand the students, recognize the individual differences of students, and use different teaching methods.

Enhance interest of learning, improve students' motivation:

In English "speaking" is actually an active, positive expression process. The realization of this process requires that students have great interest. First teachers should select the materials that students are familiar with and like, so that when the students practice, they have something to talk about; in addition, teachers can also improve teaching methods to carry out rich and colorful teaching activities (such as pair-activities, group activities, etc.), so that in the teaching activities students can constantly change roles, keep fresh feeling, students' interest can be cultured and kept, and ultimately teaching aim to improve students' various language skills can be achieved. Teachers should play a dominant role and should be clever to ask questions, to help students overcome communication apprehension. Most vocational students lack confidence because of poor oral English level. For these students, teachers should encourage more and criticize less, in order to enhance their self-confidence.

Improve Oral English Teaching Methods. Focus on practical teaching of oral English, develop students' communicative ability:

Prominent characteristics of vocational talents are relatively strong practice and practical ability. We can see from the job market, the graduates who are good at specialty and can speak English fluently are in the ascendant. Practical and simple sentence patterns should be used in oral English teaching. The nature of oral English is simple, so teachers should not provide too many sentence patterns in class, and enough expression and communication sentences are ok. The most important thing is that students themselves can create situations, practice and use these sentence patterns, meanwhile strengthen students' self-learning ability, and encourage students to accumulate phrases and small words in daily time.

Focus on professional characteristics, and create language and cultural environment:

For vocational college students, oral English has professional characteristics. Therefore, in oral English teaching, the professional English speaking skills training need to be focused on, which can reflect the professional characteristics of vocational oral English courses. In spoken English teaching, teachers should try to make the students speak, let students choose subjects and scenarios themselves, select conversation mode, talk freely, and focus on training their communication skills.

Language is a tool of communication, and communication is always carried out in certain situations. Therefore, teachers should create scenarios for students in English as much as possible, and objects, pictures and multimedia can be used to create scenarios such as shopping, festivals, interviews etc., so that students enter the scene teachers design with curiosity to learn and use proper language in a variety of occasions. In schools with better conditions, teachers should encourage students to create their own language atmosphere in the classroom, cafeteria, dormitories and other public places at any time to communicate in English and learn the language. 
In teaching teachers should expand students 'cultural horizons, strengthen leading of Anglo-American culture, compare Anglo-American culture with the culture of their own language, enhance their awareness and ability of cross-cultural communication, and strengthen students' habit of thinking in English. To train students 'ability to think in English, in teaching teachers should make brief introduction to customs, history, cultural traditions, values, and expression habits etc. in English-speaking countries, to improve students' cultural sensitivity.

Train skill-oriented oral English teachers. Improve the teaching skills of oral English teachers:

To improve the oral English teaching level, teachers must first learn the advanced educational philosophy, and change the traditional teaching concept of oral English of vocational colleges. Concept should be changed from Exam-Oriented education into skill-oriented education, through teaching teachers ought to be fully aware that English is an important tool for learning cultural knowledge, obtaining information and international exchanges rather than cope with test, and should abandon the traditional and outdated teaching concept which target on imparting knowledge and dealing with exam while ignoring the students' skills training; and in the class "teacher-centered" should be changed into "student-centered". English teachers should be good at providing a platform for students to speak English and have something to say, make students become the leading role of oral English class.

Improve the oral English level of teachers:

Students' level of spoken English relies on teachers' oral English level, so train outstanding teachers are the key to spoken English teaching of vocational colleges. Effective ways to improve the level of oral English teachers are: improve and strengthen the English teacher evaluation system, and enhance the overall level and operational capacity of English teachers; encourage teachers to participate in spoken English training in and out of school, and provide teachers with the opportunity to study abroad to improve their spoken English.

Compile school-based teaching materials, and improve spoken English practical books of vocational colleges. In oral English teaching of vocational colleges, the textbook is the main basis of teaching content. First, the textbooks should have moderate degree of difficulty, the teaching materials should be interesting, and also systematic and targeted. Second, contents should be easy to understand, step by step, exercises should be carefully designed and be in lively form. Third, vocational colleges mainly train skilled personnel, therefore, professional content should be taken into account in teaching materials, and it should reflect the professional characteristics. Fourth, textbooks should have multilevel nature in language level, which will help to train the spoken English ability of students in different professional backgrounds, and adapt to long-term characteristics of improving oral English. Fifth, textbooks can be compiled in a more flexible form, including the base portion, a professional supplement or "choose to learn" parts. Sixth, teachers should introduce in Spoken English teaching materials the differences in our society, culture and customs, etc. between Anglo-American countries and China, to help students correctly understand English and learn to express their ideas, attitude and emotion at different occasions with appropriate English.

\section{Conclusion}

In modern society, people's exchanges throughout the world are strengthened, while English is a widely used language, so the ability of speaking fluent English has been one of the basic qualities of modern people. However, in present situation, English communicative competence of students in vocational colleges is generally poor, so their spoken English should be improved. Therefore, the oral English teaching reform is extremely urgent. Despite difficulty, it is entirely achievable through some efforts to make vocational students speak fluent English. 


\section{References}

[1]. Sun Chun Lei. On Content-Based Instruction Assessment. Journal of Chongqing Institute of Technology, 2000 (4): 91-94.

[2]. Wang Jian-mei, Pu Yun-ling, Sun Chun- Lei, "CBI and Its Application in College English Teaching of China." Journal of Chongqing Institute of Technology, 2001(6):111-15.

[3]. Wu Qinglin. Cognitive Psychology of Instruction. Shanghai: Shanghai Science and Technology. 2000.

[4]. Cao Peisheng. Study on the College English Teaching Pattern CBI effectiveness. Foreign Language Education, 2012 (5): 51-55.

[5]. Dai Qingning, Lu Hua. CBI teaching philosophy and teaching. Foreign Language Teaching, 2004 (4): 16-20.

[6]. Deng Huiyu.On CBI Teaching Mode Thematic Validity Vocational Business English Teaching. CULTURE, 2011 (4): 140-42

[7]. Zhang Qin. Problems and Solutions of Task-based Teaching Mode in Spoken English Teaching in Vocational Colleges [J]. JOURNAL of Tai'an College of Education, 2010(6):35-38.

[8]. Huang Ting-ren. Plans on Spoken English Teaching Reform. Journal of Guangdong Ethnic Institute (Foreign literary language album), 1997(12):26-30.

[9]. Ge Liang. Analysis of Oral English in Higher Vocational Colleges and Reform Strategies. Educational research of Curriculum, 2013(11):17-20.

[10]. [10]. Fogarty, Robin. The Mindful School: How to Integrate the Curriculum. Palatine, IL:Skylinght. 1991. 